Journal of Southeast Asian

\title{
Academic Needs and Family Factors in the Education of Southeast Asian American Students: Dismantling the Model Minority Myth
}

David M. Lee

San Diego State University, david.lee104@gmail.com

Luke Duesbery

San Diego State University, duesbery@mail.sdsu.edu

Peggy P. Han

San Diego State University, peichenhan@gmail.com

Thupten Tashi

San Diego State University, ttashisd@yahoo.com

50 Years of Model Minority Stereotype Research

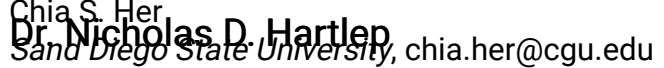

Metropolitan State University

Follow this and additional works at: https://docs.lib.purdue.edu/jsaaea

c.

Part of the Bilingual, Multilingual, and Multicultural Education Commons

\section{Recommended Citation}

Lee, David M.; Duesbery, Luke; Han, Peggy P.; Tashi, Thupten; Her, Chia S.; and Ooka Pang, Valerie (2017)

"Academic Needs and Family Factors in the Education of Southeast Asian American Students:

Dismantling the Model Minority Myth," Journal of Southeast Asian American Education and Advancement.

Vol. 12 : Iss. 2, Article 2.

DOI: $10.7771 / 2153-8999.1154$

Available at: https://docs.lib.purdue.edu/jsaaea/vol12/iss2/2

This document has been made available through Purdue e-Pubs, a service of the Purdue University Libraries.

Please contact epubs@purdue.edu for additional information.

This is an Open Access journal. This means that it uses a funding model that does not charge readers or their institutions for access. Readers may freely read, download, copy, distribute, print, search, or link to the full texts of articles. This journal is covered under the CC BY-NC-ND license. 


\section{Academic Needs and Family Factors in the Education of Southeast Asian American Students: Dismantling the Model Minority Myth}

\section{Authors}

David M. Lee, Luke Duesbery, Peggy P. Han, Thupten Tashi, Chia S. Her, and Valerie Ooka Pang 


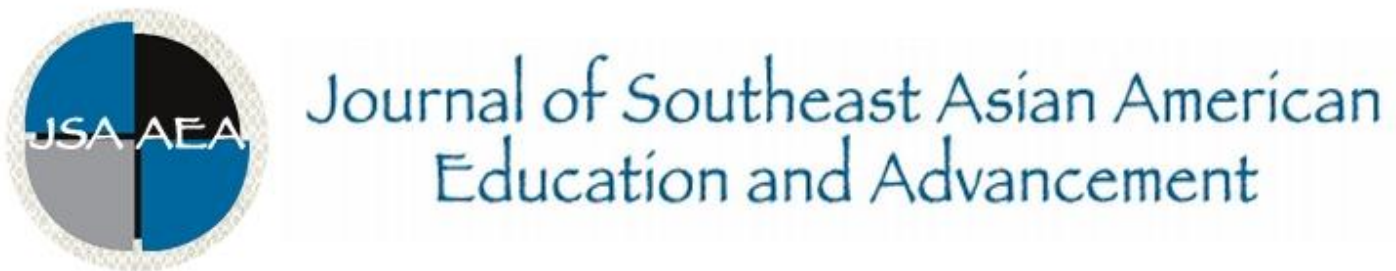

Vol. 12 Iss. 2 Special Issue (2017)

WWW.JSAAEA.org

\title{
Academic Needs and Family Factors in the Education of Southeast Asian American Students: Dismantling the Model Minority Myth
}

\author{
David M. Lee \\ San Diego State University \\ Luke Duesbery \\ San Diego State University \\ Peggy P. Han \\ San Diego State University \\ Tashi Thupten \\ San Diego State University \\ Chia S. Her \\ San Diego State University \\ Valerie Ooka Pang \\ San Diego State University
}

\begin{abstract}
The model minority myth is a powerful force in schools. Many teachers believe that Asian American students do not need academic interventions. The purpose of this study was to examine the student achievement of almost a million seventh-grade students from California. The research compared the performance of Southeast Asian Americans, Cambodian, Laotian, and Vietnamese students, on reading and math on the CAT/6 standardized assessment with African American and White American students. Cambodian American and Laotian American students performed significantly lower than their White American peers and compared similarly to their African American peers. Vietnamese American students also scored lower than their White American counterparts on reading. In addition, the study examined the influence of parent education levels, free/reduced lunch status,
\end{abstract} and no alteration or transformation is made in the work. More details of this Creative Commons license are available at http://creativecommons.org/licenses/by-nc-nd/3.0/. All other uses must be approved by the author(s) or JSAAEA. 
and ethnicity on academic achievement. A huge achievement gap continues to plague many Southeast Asian American students.

Keywords: Southeast Asian Americans, Cambodian, Laotian, Vietnamese, White, African American, California Achievement Test, Parent Education Levels

\section{Introduction}

The "model minority" myth has been an issue that has affected all Asian American communities. This article presents research which dismantles the stereotypical façade that has been constructed in order to reveal the harm that it produces. Although this label had originally applied to Japanese, Chinese, and Korean Americans, it has come to envelope and affect all Asians in the United States. Grouping together such diverse ethnicities has perhaps been most detrimental towards Southeast Asian Americans especially Laotians, Cambodians, and Vietnamese. A dichotomous relationship exists as a result in which the image of the successful Asian American student contrasts sharply with data that reveals that Southeast Asian American groups exhibit some of the lowest educational outcomes in American schools regardless of race or ethnicity.

The origin, evolution, and symbolic significance of the "model minority" myth will be analyzed and providing a nuanced understanding of Southeast Asian American students using disaggregate data of Vietnamese, Cambodian, and Laotian American students as they compare with their White and African American counterparts from the state of California will be provided. The 2008 total-population data is comprised of the performance of seventh-grade students on the standardized California Achievement Tests, Sixth Edition Survey (CAT/6 Survey or CAT/6).

\section{Using Disaggregated Data to Dispel the Model Minority Myth}

One of the major points made in this study is the importance of using disaggregated data to describe the achievement of Asian American and Pacific Islander (AAPI) students (Pang, Han, \& Pang, 2011). Aggregated data has been used to reinforce the model minority myth and to disregard the educational needs of AAPI populations. The utilization of aggregated AAPI data to describe the academic performance of numerous ethnic communities has been an institutional and structural way to reinforce the American belief in meritocracy and social justice. The aggregated bolsters the idea that equal opportunity is a reality for all AAPIs; however, the data in this study and others have shown that the aggregation of data presents a damaging overgeneralization about AAPI achievement (Pang et al., 2011; Suzuki, 2002). In education, the use of aggregated data has led to the reinforcement of the model minority myth. The high academic performance of some Asian American groups masks the lower and problematic achievement of other Asian American students.

Few services are provided to AAPI students who are in need of academic, mental health, artistic, and leadership skills due to the pervasive belief in the model minority myth. Educators and other scholars have misused statistical methods which has served as an obstacle to providing AAPI students equal opportunities. 


\section{Model Minority Myth}

The inaccuracies, oversimplifications, and political leveraging that has all contributed to the construction of the "model minority" label has had real world societal effects upon all AAPIs (Her, 2014; Nyugen, 2014; Osajima, 2008; Pang et al. 2011; Pang, Kiang, \& Pak, 2004; Sue \& Okazaki, 1990; Suzuki, 2002; Zhang, 2010). The power bestowed onto such a myth in which vastly diverse Asian ethnic groups are homogenized and packaged by outside political and social designations has had far-reaching educational ramifications that are still being unpacked by scholars today. For example, teacher perceptions of AAPIs as only being successful may result in their academic needs being ignored, even among those who are failing. The influence and reach of this perception has seeped into America's subconscious of which school policies and public discourse which further perpetuate such stereotypes. On the surface, the "model minority" myth may seem complimentary and enviable, especially in comparison to labels applied to other racial groups. Yet, such easy and simplified comparisons may have been the exact reason for creating this myth in the first place. Accepting vast generalizations of AAPIs as the pinnacle of success has opened the door for the social and educational critique of all other minority groups. The discourse, which is enforced against African American and Latino/a groups, is that they are not trying hard enough in school and society at large. This discourse creates arguments against their collection of state resources and services. Yet, using one racial classification to homogenize several different AAPI student communities has created the false perception that they are all successful; this is contrary to the reality that many Southeast Asian American groups need assistance like other ethnic racial groups such as African Americans.

\section{The Beginning of the Model Minority Myth}

William Petersen is credited as the first person to use the term "model minority" in a January 1966 article in the New York Times Magazine to laud the efforts of Japanese Americans and their assimilation into American society. U.S. News and World Report then followed this trend by using the "model minority" label to describe Chinese Americans and their hard work, morality, and thriftiness evidenced by their capacity to build a peaceful and prosperous Chinatowns despite facing enormous racial discrimination (Osajima, 2008). Osajima (2008) contends that this image of "success" rested on two premises that people believed to be true. First, statistical data was used to substantiate the myth that Asian Americans were able to increase their income, hold high status jobs, and have low rates of crime and mental illnesses. Additionally, many White Americans thought that AAPI cultures held values and traditions such as parental respect and authority, industriousness, obedience, and willingness to learn, which were perceived to directly affect their high educational achievement and professional occupations (Lew, 2004; Li, 2005; Suzuki, 2002). Some scholars noted that the "model minority" stereotype unofficially demonstrated that Asian Americans had finally been accepted by White middle-class society as a result of their hard work (Pang \& Cheng, 1998; Park, 2011; Suzuki, 2002). Yet, the "model minority" stereotypical perception disguises the reality that AAPIs in America are not accepted in many sectors of society even compared to other minority groups (Hartlep, 2013; Nguyen, 2014; Pang, Han, \& Pang, 2011; Sue \& Okazaki, 1990). Why the sudden change, when for a century Asian Americans were portrayed by the media as the invading "yellow peril," in which they were characterized as depraved and uncivilized heathens who were a threat to the American way of life (Miller, 1969; 
Ogawa, 1971). Suzuki (2002) attributed the sudden change in image to the charged political, social, and racial climate of the mid-1960s in which society was undergoing rapid transformations due to the Civil Rights movement.

\section{"Model Minority" and the Media}

Petersen's nascent 1966 article about the "model minority" grew in influence as television, advertising, magazines, and movies in turn shaped and imprinted this Asian stereotype onto the American consciousness (Zhang, 2010). Yet the perceptions of Asian females and males tended to differ in which Asian women were seen as silent, obedient, exotic, hyper-sexualized, seductive, and ruthless dragon ladies (Lee \& Joo, 2005; Park, Gabbadon, \& Chernin, 2006). Asian men were perceived as effeminate, culturally ignorant, asexual, isolated, subservient, martial artists, or cunning villains (Lee \& Joo, 2005; Yuen et al., 2005). Contradictory perceptions were generated to represent one racial group, especially among AAPI males in which on the one hand they were thought to be uneducated, and unassimilable foreigners yet today a complete reversal has occurred in which they are thought to be intelligent, successful, obedient, and conforming "model" minorities (Suzuki, 2002). Zhang's (2010) study revealed the negative effects these popular portrayals had on the lives of typical Asians living in America. He discovered that AAPI more than any other racial/ethnic groups were most likely to be perceived to be academically successful yet at the same time rejected by their peers and least likely to be approached by others seeking friendship because of their impression as "nerds" who lack social skills and connections (Zhang, 2010).

\section{The Political and Social Environment}

Osajima (2008) described the racially charged milieu of the mid-1960s when the Civil Rights movement was in full swing, resulting in race riots and Black militancy. During this time, the myth of the "model minority" began germinating vis-á-vis the accomplishments of one million Japanese and Chinese Americans who became models of success and eventually came to include other Asian subgroups including Korean, Vietnamese, and Filipino Americans (Osajima, 2008). One of the main motivations behind creating the "model minority" stereotype may have derived from the political motivation to create a dichotomous relationship pitting African Africans who received support through federally funded welfare programs against Asian Americans who had pulled themselves up by their own bootstraps (Petersen, 1971). This dynamic placed the burden of blame squarely on the shoulders of African Americans as the reason why there was such disparity in their educational and socioeconomic attainment. People who work hard do well in society. Those who do not achieve are not persistent or hard working. The backbone of the "model minority" rests on the unspoken premise that American society was not racist or discriminatory but built on meritocracy and fairness regardless of race, religion, or national origin (Osajima, 2008). The "model minority" stereotype reveals the intricate complexities behind such generalized notions of race and achievement. As a result, individuals have the unfair burden of being compared to these pre-established stereotypes rather than having full agency to construct their personal identities based on their own capabilities and character. Additionally, Osajima (2008) found that AAPI parents put a tremendous amount of pressure on their children to achieve in school without 
allowing for other avenues of success which naturally created resentment and angst among the younger generation.

\section{Influx of Asian Immigrants}

The passage of the 1965 Immigration Act was originally designed to exclusively increase European numbers in the United.States. by allowing 20,000 immigrants per country per year. Unintentionally there also was an increase in Asian immigrants (Odo, 2002; Osajima, 2008). From 1970 to 1980, the Asian population in America grew at a rapid pace from 1.4 million to 3.5 million (Osajima, 2008). The influx of AAPIs from diverse countries still did not change the narrow view which homogenized all AAPI ethnicities within one stereotype. Over time, greater numbers of AAPI students began matriculating into schools especially at top tier universities and became more visible and identifiable as academically successful which only added to the myth (Osajima, 2008). Yet, this perceived success was a "double-edged" sword in which Asian Americans were pigeonholed as only able to thrive in the academic arena and emphasized their single-minded focus on achievement (Zakeri, 2015).

\section{The Story of Southeast Asian Immigrants}

The strategic location of Southeast Asia in the Vietnam War era brought U.S. military interests in this region. As a result of war, many diverse Southeast Asian groups particularly the Vietnamese, Laotians (Lao and Hmong), Cambodians, and ethnic Chinese came involuntarily to the United States as refugees through special programs even though they did not meet visa or quota requirements (Kitano \& Daniels, 2001). The "first wave" of Southeast Asian refugees during 1975 was composed primarily of the professional and intellectual class, while the "second wave" consisted predominately of laborers who were forced to scatter throughout the Unite States. despite the vast majority eventually migrating to the Sunbelt states, especially in California (Kitano \& Daniels, 2001; Lam, 2015; Odo, 2002). From 1970 to 1980, the Southeast Asian population had grown from 20,000 Vietnamese to 415,235 Indochinese; 78 percent were Vietnamese, 16 percent Cambodians, and 6 percent Laotian, with numbers that kept growing in subsequent decades (Kitano \& Daniels, 2001).

\section{Adaptation to the United States}

The fallout from war, asylum in refugee camps, and the sudden relocation to the United States produced an adaptation process that can be described as a clash of cultures. Cultural pressures calling for Hmong women to marry during their childhood has had the effect of producing early school dropouts and the highest welfare rate among any group in the United States. despite these young women having had high academic achievement while in school (Kitano \& Daniels, 2001). A 1985 Los Angeles Times article described an unusual case of cultural maladjustment in California when an apparent suicide by a Hmong man occurred due to the shame and confusion following a mere traffic violation (King \& Holley, 1985). A window into the Hmong culture reveals that they did not have a written language until the arrival of missionaries in the 1950s and 
distrusted modern medicine, which placed heavy tolls on the younger generation in the United States to take care of their elders who were even fearful of driving or being driven in cars (King \& Holley, 1985). The seeds of conflict and relocation to a new land produced the emergence of Southeast Asian American youth gangs especially among the Vietnamese (Lam, 2015). According to Reyes (2007), the "model minority" stereotype fails to take into account the complex identities of Southeast Asian Americans, especially among the younger generation, who try to distance themselves from the foreigner or "model" Asian image.

\section{Contemporary Discourse of the "Model Minority"}

The image of the "model minority" in contemporary times has undergone slight changes while still retaining political overtures. Omi and Winant (2015) argue that a "rearticulation" of the Asian American successful image has occurred due to the infusion of key elements of conservative political ideology. Conservative scholars such as Thomas Sowell described Asian American families as "better" because they work harder than other groups (Osajima, 2008). Such descriptions and perceptions denote the underlying power dynamics in the United States where minority groups are judged by those in power and either praised or chided based on generalizations. The political message underlying these portrayals is that the key determinant of success comes down to individual effort instead of structural problems within schools which affect every racial group differently (Wing, 2007).

\section{Myth vs. Reality}

Some people may mistake success stories embedded in the "model minority" myth as reality when in fact these stories are typically not the norm. There are incidents where the high expectations placed upon AAPI students by their parents, teachers, and peers have caused stress and alienation leading to academic decline, school dropouts and even suicide especially among females (Kumashiro, 2008; Pang, 1991; Sue \& Morishima,1982; Sue \& Zane, 1985).

In response to the needs of AAPI students, the Asian Pacific American Education Advisory (APAEA) Committee of the California State University (CSU) system was established by the chancellor in 1989 in order to provide any means of help for all enrolled AAPIs (Suzuki, 2002). This committee's major findings revealed that AAPI students for whom English was a second language (ESL) were delayed from graduating by one or more years due to their lack of proficiency on English writing tests (Suzuki, 2002). The CSU schools provide ESL support but did not realize that AAPI students felt intimidated, unwelcomed, and excluded by the staff who were indifferent to their problems and needs, a phenomenon not only endemic to CSU campuses but other campuses around the country (Suzuki, 2002). AAPI ESL students were marginalized because of the "model minority" stereotype whereby all AAPIs were thought to be successful in their educational pursuits. Other racial groups find empowerment and a greater sense of efficacy in seeking help instead of being met with stereotypes and discouragement. Pang (1990) and Suzuki (2002) believe that AAPIs in the United States do not receive the help and encouragement to pursue majors in fields which require well-developed verbal or linguistic skills since the "model minority" stereotype suggests that they are "problem-free" high achievers. These scholars also believe that leadership programs are critical in developing communication and public-speaking skills which 
are needed to assume managerial positions in the workplace (Pang, 1990). Instead, these students are compelled to major in science, technology, engineering, and math (STEM) related fields; this impacts their low visibility for leadership roles at universities and other professions (Suzuki, 2002).

\section{The "Model Minority" through U.S. History}

Todd Gitlin (1982), a well-known sociologist, aptly stated that hegemonic ideologies "stand still, in a sense, by moving." This statement describes the perpetual nature of the "model minority" stereotype, which has remained etched on the American consciousness since the 1960s despite major changes in the socio-political landscape (Osajima, 2008). This stereotype has moved from the pages of news articles to television, movies, and popular culture, which transforms connotation into reality; a reality that describes AAPIs as one-dimensional people focused on educational success. Yet the research literature demonstrates that the "model minority" is a myth rather than fact, especially when describing all Asian Americans. Many scholars (Lew, 2004; Ngo, 2006; Pang, Han, \& Pang, 2011; Park, 2011; Wing, 2007) contend that AAPIs are neither a homogenous group nor collectively experience educational success. In fact, this term has caused greater divisions among AAPI subgroups in which certain ethnicities such as the Hmong who struggle educationally and economically are labeled as "Americanized" and "bad" as opposed to the "traditional" and "good" AAPI (Lee, 2005; Lew, 2006; Park, 2011). This term is not only detrimental to AAPIs who may underachieve but also to those who are successful because they are relegated to inhabit and manifest a caricaturized version of a stereotype in other peoples' eyes.

\section{Southeast Asian Americans: The Model Minority Myth}

Hartlep (2014) suggested that teachers and school administrators need to better discern the fact that there are various Asian ethnicities with their own unique cultures, histories, and complex identities. These differences play a critical factor in how certain Asian Americans shape their lives in relation to the "model minority" myth. For instance, Lam's (2015) research into Southeast Asian American and particularly Vietnamese American migration history reveal that the greater structural forces, such as poverty and the context of these refugee groups, produced youth gang members as they grew up in America. Such an identity, which is seemingly contradictory with the "model minority" stereotype, illustrates the multidimensional character of the Asian American identity which is infused with family history, class, as well as other cultural influences.

Intergenerational conflicts also occur in many Southeast Asian families (Chhuon, Hudley, Brenner \& Macias, 2010; Choi, He, \& Harachi, 2008; Shah, 2007). Choi and her colleagues (2008) explained that many Cambodian American and Vietnamese American young people clash with their parents because they adopt more mainstream values. Parents were concerned because they lost so much of their familial authority when they migrated to the United States. The increase in intergenerational conflict leads to less parent-child bonding of both Vietnamese American and Cambodian American parents and their children. Many parents, no matter how long they had lived in the United States, saw the erosion of cultural values as a threat to the family (Choi et. al., 2008). For example, Choi and her colleagues found that about 43 percent of their Vietnamese American sample and 65 percent of the Cambodian American teenagers reported that they were involved in fighting, shoplifting, teasing, and staying out late at night. Shah (2007) studied members of Laotian 
American families and also found intergenerational conflict. However, she discovered there was an emphasis on family that permeated the lives of many Laotian youth. Numerous adolescents also valued family time and enjoyed cooking together, sharing meals, and speaking in Lao or Mien.

Cambodian American adolescents also may not have the same social capital of other AAPI groups such as Chinese Americans and Japanese Americans (Eng, 2012). Eng found that many Cambodian American families did not reside in the same area for an extended period of time and this led to the lack of developing extensive social networks that could be of assistance to their children. In addition, parents were less likely to be involved in schools, however they did provide time for their children to do their homework and encouraged them to get good grades. Many families were members of families living in poverty therefore the students did not have the same opportunities for afterschool activities as their mainstream peers.

Research has found that many Cambodian American, Laotian American, and Vietnamese American high school students are often not ready to enter college (Her, 2014). Her found that in the Early Assessment Program which is a collaboration of the California Department of Education, the California State Board of Education, and the California State University system have instituted a system where the readiness of eleventh graders in math and English is assessed. They take placement assessments and if they do not show proficiency on the college level, the students must take remedial courses in their freshmen year. For example, 64 percent of the Cambodian American students who took the exam in English in 2013 were identified as not college ready. Seventy-three percent of Laotian American students and forty-three percent of Vietnamese American high school students that same year were also found not prepared to enter college in English.

\section{Conflation of Perception and Statistics: College Graduation Rates}

Suzuki (2002) believed that the higher college graduation rates among AAPIS, 38 percent versus 20 percent of the U.S. population based on 1993 U.S. Census Bureau data, helped to substantiate the "model minority" myth. Also, the socioeconomic status of AAPIs had risen since the 1970s along with the immigration levels from economically prosperous Asian countries such as Japan, China, and Korea which caused some in the public to draw a false causal relationship between these two phenomena (Stokes, 1987; Wallace, 1982). This simplistic level of analysis belies the truth. Recent studies suggest that since the late 1980s, White Americans consistently received a higher rate of return on the same level of education than AAPIs (Cabezas \& Kawaguchi, 1988; Federal Glass Ceiling Commission, 1995; Hune \& Chan, 1997; Jiobu, 1988; Wong \& Nagasawa, 1991; Woo, 2000). For AAPI, the high level of education they had acquired was relatively problematic compared to their female counterparts because of the "glass" or "bamboo" ceiling (Hyun, 2005; Woo, 2000) whereby they would consistently lose out to similarly qualified White men in the workplace especially in management positions (Pang, Han, \& Pang, 2011; Woo, 2000). For instance, at institutions of higher education, AAPI full-time faculty totaled 31,259 or 5 percent in 1997, yet there were only 2,736 or 2 percent in executive, administrative, or managerial positions (Number of Full-Time Faculty Members by Sex, Rank, and Racial and Ethnic Group, 2000; Characteristics of College Presidents, 1995, 2000). When certain positions are based purely

on credentials, AAPIs seem to have a competitive chance at obtaining a job, yet when the position involves more abstract qualifications such as perceptions of leadership, AAPIs, especially men, fall to the wayside. 


\section{Individual Incomes of Cambodian, Laotian, Vietnamese, Blacks, and Whites}

One of the demographic measures used to describe the financial health of communities is data on individual incomes. There are numerous AAPI communities that live in poverty. Figures 1 and 2 provide information about the ethnic and racial groups highlighted in this study. See Figure 1 for the percent of individuals living below the poverty line in the Cambodian American, Laotian American, and Vietnamese American populations. Figure 2 provides a visual display of the differences among the individual incomes in the ethnic/racial groups. The three-year estimate from 2007 through 2009 for Whites is the highest at $\$ 23,640$. This is in comparison to Cambodian Americans and Laotian Americans at \$16,000, Vietnamese Americans at \$21,000 and black Americans at $\$ 16,300$. White Americans earn substantially more than the AAPIs and Black American individuals. Cambodian Americans and Laotian Americans have some of the lowest person incomes of AAPIs (National Commission on Asian American and Pacific Islander Research in Education, 2008).

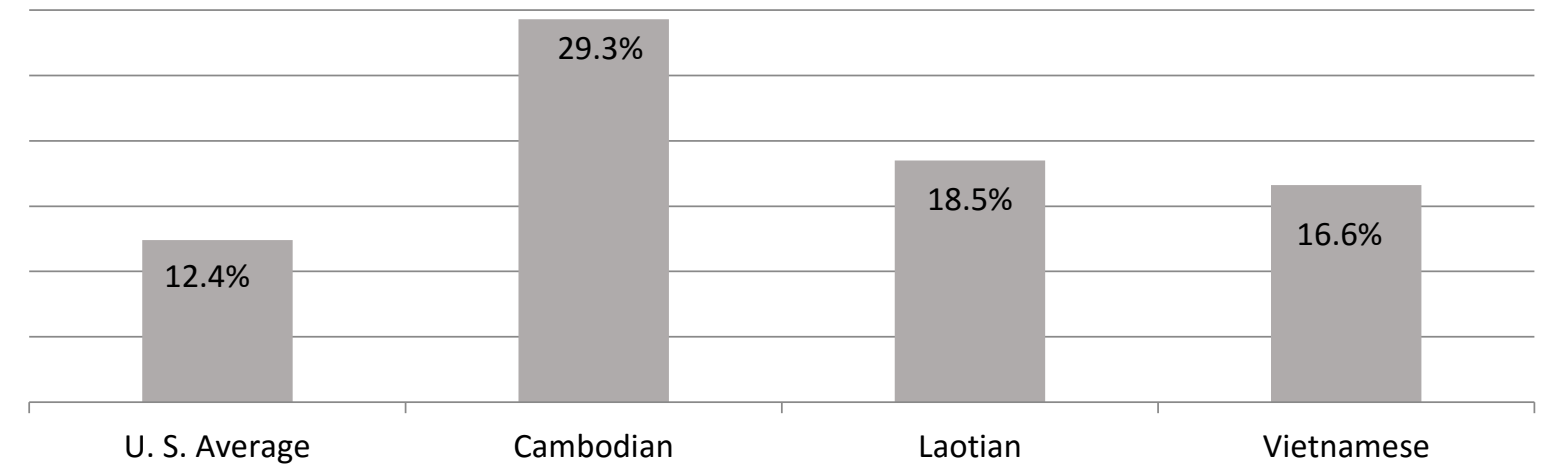

Figure 1. Percent of Cambodian Americans, Laotian Americans, and Vietnamese Americans Living in Poverty.

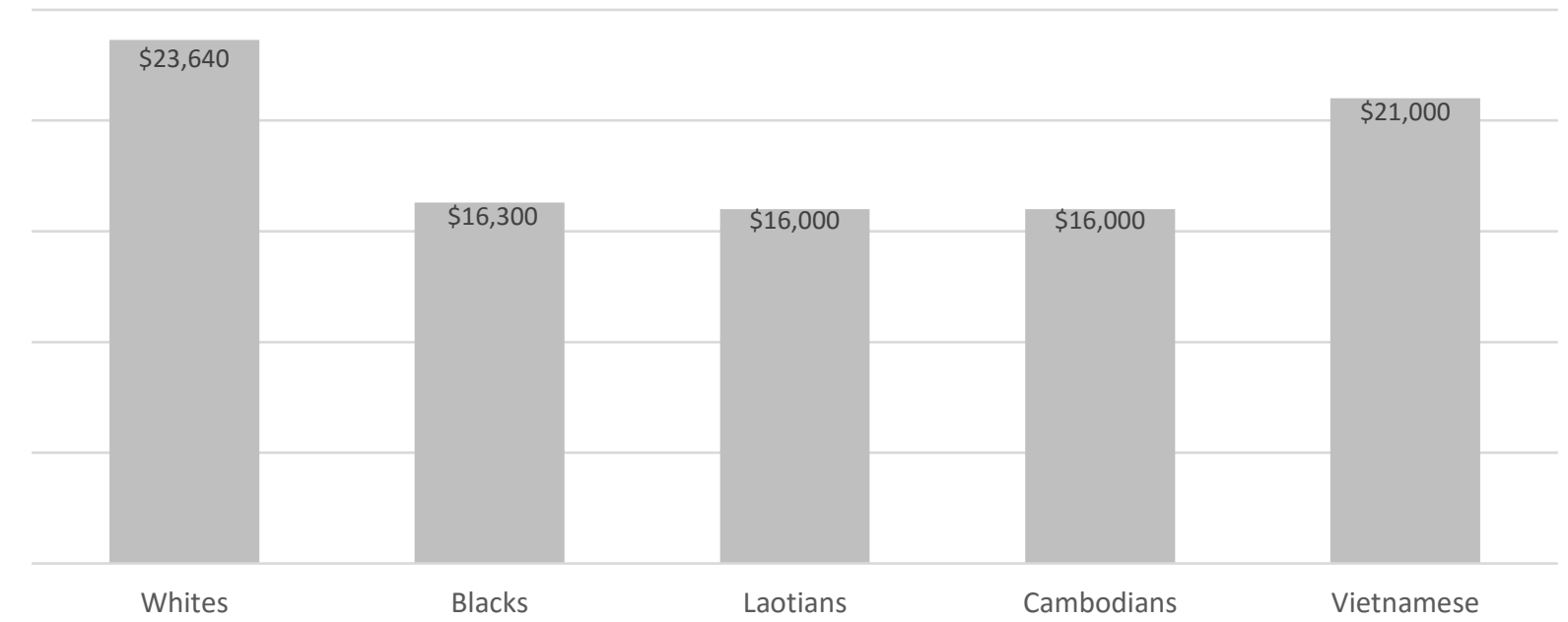

Figure 2. Individual Incomes. Cambodian Americans, Laotian Americans, Vietnamese Americans, African Americans, and Whites, 2007-2009 (U.S. Census Bureau, 2007-2009 American Community Survey, 3-year Estimates, 2011). 


\section{Educational Attainment}

U.S. Census data demonstrate that a limited number of Southeast Asian Americans 25 years and older have earned a bachelor's degree or graduate degree; 18 percent of Cambodian Americans, and 28.4 percent of Vietnamese Americans have attained this level of education. Disaggregated 2007-2009 American Community Survey 3-Year Estimate (2011) data shows that the educational attainment of Cambodian, Laotian, and Vietnamese Americans are similar to African Americans and Latinos. A more comprehensive view of educational attainment of AAPIs can be found in Table 1. This information demonstrates the wide range of diversity within the AAPI community in regard to educational attainment of those who are 25 years and older. In 2000, 53.3 percent of Cambodian Americans, 40.6 percent of Laotian Americans, and 38.1 percent of Vietnamese Americans never graduated from high school compared to 19.6 percent of all U.S. adults (National Commission on Asian American and Pacific Islander Research in Education, 2008). Figure 3 also depicts this data.

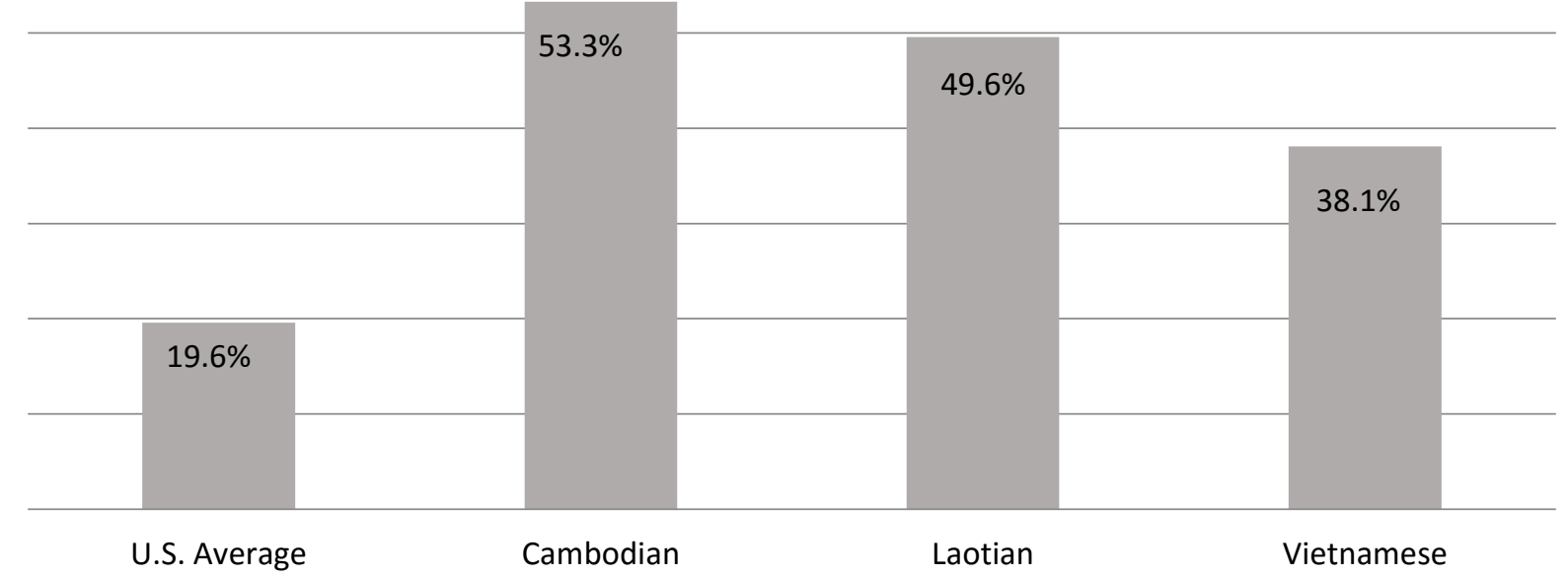

Figure 3. Educational Attainment. Percentages of AAPI groups with less than a high school degree in 2000.

The previous sections have provided a context for this research. The "model minority" myth is a powerful stereotype that has influenced how educators and others perceive Southeast Asian American and other AAPI students. The historical and financial status described characterizes the diversity within the AAPI student population.

\section{Methods}

\section{Research Population}

It is difficult to locate comprehensive achievement data that includes Cambodian, Laotian, and Vietnamese students. Most school districts and large national organizations collect data as an AAPI aggregate. The data included in this study were part of California's evaluation and assessment of student performance (California Department of Education, 2003b, 2004). Since the number of Cambodian American and Laotian American students was small in comparison to the 
other groups, they were combined. The data also included White and African American students in 2003 through 2008.

\section{Research Questions}

Researchers focused on the following two questions: (1) For both reading and math, how does the academic achievement of Cambodian American, Laotian American, Vietnamese American, and African American seventh-graders compare with that of their White American peers on the CAT/6 from 2003-2008? Similarly, (2) For both reading and math, how do lunch status, parent education levels, and ethnicity influence the achievement of Cambodian American, Laotian American, Vietnamese American, and African American seventh-graders compared with that of their White American peers on the CAT/6 from 2003-2008?

\section{Instrument}

In April of 2002, the state of California adopted the California Achievement Test Sixth Edition (CAT/6) (California Department of Education, 2003b; 2004) and utilized it as a norm-referenced test to compare student achievement in the state with a national sample of students in the same grade. California administered standardized achievement tests to all seventh-graders on the CAT/6 between 2003 through 2008. The CAT/6 is a norm-referenced standardized test through which student scores can be compared to the performance of a national representation of students (California Department of Education, 2003a; 2004). This assessment is not used for individual student evaluation. California eliminated the use of the CAT/6 in the 2008-2009 school year because of the lack of financial resources.

The Normal Curve Equivalent (NCE) scores of the CAT/6 were used in this study. The Normal Curve Equivalent (NCE) score scale was developed in the mid-1970s by the U.S. Department of Education to better allow for cross study comparison (Talmadge \& Wood,

1976). The scores range from 0 to about 100, the mean is set to 50, and the standard deviation $(s d)$ to 21.06 (for reasons associated with the normal curve). Figure 4 portrays the scaling compared to standard deviation units and percentiles.

In this study, NCE scores are used for all the analyses. NCE scores were initially screened for the requisite assumptions associated with each statistical procedure prior to analysis. The boxplot, histogram, and normal probability plot, along with the normality test were conducted to provide information on the normality of the population distribution. 


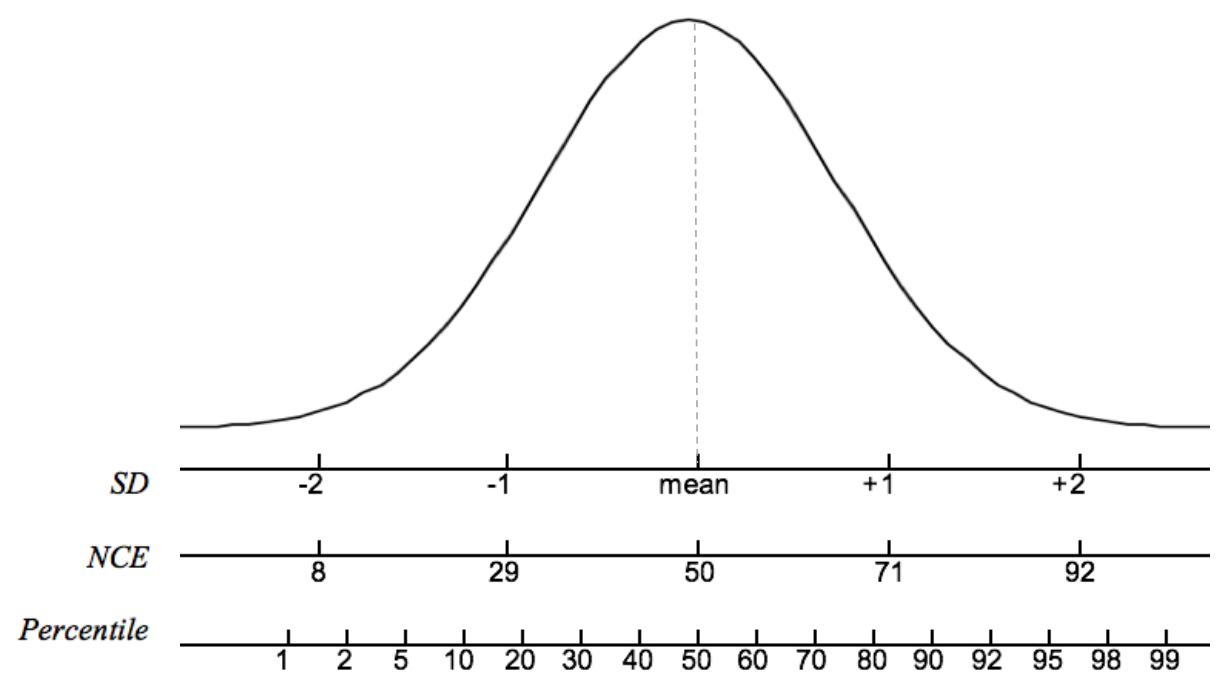

Figure 4. Normal Curve Equivalents. NCE score compared to standard deviation and percentiles. The NCE score mean is set to 50 and the standard deviation to 21.06 .

\section{Study Variables}

In addition to ethnicity and race (White, African American, Laotian American, Cambodian American, and Vietnamese American), the following variables were used: federal student lunch status (free/reduced lunch, no free/reduced lunch), and parent education level (4 levels: less than high school, high school graduate, some college, and college graduate/post graduate school). Lao and Cambodian data were combined because of the smaller numbers of students in the population compared to the other groups. In addition, social economic status was defined through the use of student school lunch eligibility which was based upon the income requirements of the National School Lunch Act (2013). Each year the federal government provides guidelines for family income levels. For example, in 2007-2008 a family of four could not earn more than $\$ 26,845$ annually to be eligible for free lunch status and $\$ 38,203$ annually to be considered reduced lunch participants (U.S. Department of Agriculture, 2007).

\section{Statistical Analysis}

Similar to the research conducted by Pang and her colleagues (2011), data from CAT/6 include raw scores, scaled scores, national percentile rank (NPR) scores, normal curve equivalent (NCE) scaled scores, and stanines (standard nine). NCE is a way of standardizing scores, and its use is a major advantage because the values can be averaged. The analyses utilized Analysis of Variance (ANOVA) to test for academic performance differences among different ethnic groups. The Games Howell post-hoc test was applied for unequal variance on student populations. Statistical analyses were performed using SAS version 9.41 (SAS Institute, Inc., Cary, NC) and IBM SPSS statistics 23 (SPSS Inc., an IBM Company, Chicago, IL). 


\section{Effect Size}

A deeper understanding of differences among groups can be facilitated by a presentation of an effect size (American Psychological Association, 2010). While statistical significance leads us to understand that differences are probably not due to chance, an effect size can help us quantify the magnitude of differences. In many respects it is a more meaningful statistic when making everyday decisions. For example, if there is a statistically significant difference in achievement based on ethnicity we would not necessarily implement a national intervention strategy if that difference was negligible in magnitude. In terms of real decision making and allocating resources in a closed system, we need to better understand how much difference there is, not just that there is a difference. Gene Glass put it well, "Statistical significance is the least interesting thing about the results. You should describe the results in terms of measures of magnitude-not just, does a treatment affect people, but how much does it affect them." (as cited in Kline, 2004, p. 95)

As a result of the transformation from raw scores to NCEs, traditional effect size estimates are known to be diminished by comparison (Mclean, O’Neill, \& Barnette, 2000). While the traditional eta-squared values are presented, we recognize that "practical significance is not an inherent characteristic of the numbers and statistics [...] it is something that must be judged in some context of application" (Lipsey, Puzio, Yun, Hebert, Steinka-Fry, Cole, Roberts, Anthony, $\&$ Busick, 2012, p.26). Since the scores are directly mapped onto a normal distribution they are particularly well suited for both averaging and interpreting effect size directly. To help interpret effect sizes Cohen (1988) attributed text labels to effect sizes as follows: About or above 0.8 is large, about or above 0.5 is medium, and about or above 0.2 is small. Cohen has identified different benchmarks depending on the statistical measures utilized (Ellis, 2010). For example, in ANOVA with relevant effect size of $f$, he identified about .10 as small, about .25 as medium, and about .40 as large. Less might be termed negligible. It has become standard practice in the field of educational research to interpret effect sizes with these broad labels (Hill, Bloom, Black, \& Lipsey, 2007).

\section{Results}

The total population studied was about one million students. The seventh-graders from the state of California included five ethnic/racial groups: White, African American, Vietnamese, Cambodian, and Laotian. Table 1 describes the population in more detail.

\section{Table 1}

Demographic Characteristics of Seventh Grade Students on the CAT/6, 2003-2008 $(N=964,452)$

\begin{tabular}{lrr}
\hline & Frequency & Percent \\
\hline Ethnicity & & \\
White & 752,729 & 78.05 \\
African American & 169,214 & 17.55 \\
Vietnamese & 28,737 & 2.98 \\
Cambodian & 7,009 & 0.73 \\
Laotian & 6,763 & 0.70 \\
National school lunch program & & \\
No & 698,170 & 72.39 \\
Yes & 266,282 & 27.61
\end{tabular}


Parent education level

$\begin{array}{lrr}\text { Not a high school graduate } & 49,834 & 5.17\end{array}$

$\begin{array}{lrr}\text { High school graduate } & 195,632 & 20.28\end{array}$

$\begin{array}{lll}\text { Some college } & 297,763 & 30.87\end{array}$

College graduate/Post graduate $\quad 421,223 \quad 43.68$

\section{Reading the Math Performance: Ethnic Differences}

To assess reading performance differences by ethnicity, students' mean reading normalized scores were examined across groups. A one-way ANOVA indicated significant differences in reading performance levels across ethnic groups $F(3,964448)=30412.7, p<.0001$. Follow-up pairwise comparisons using Tukey's HSD (Honest Significant Difference) test revealed that White students $(M=58.2)$ had significantly higher reading scores compared to the Vietnamese students (mean difference, $m d=1.38)$, the Lao/Cambodian students $(m d=12.92)$, and the African American students $(m d=16.14)$. Effect sizes $(d)$ in standard deviation units ranged from negligible to large. While reading scores for White students was significantly higher than Vietnamese students, the effects size was negligible $(d=0.07)$. Similarly, differences between Lao/Cambodian and African American scores were also negligible $(d=0.15)$. Medium effect sizes were present between most other groups ranging from $d=0.55$ to $d=0.70$. There was a large difference between White and African American student scores $(d=0.77)$. Table 2 summarizes the means and standard deviations in reading by ethnic group, and Table 3 summarizes effect sizes.

To assess ethnic differences in math performance, students' mean math normalized scores were examined. A one-way ANOVA indicated significant differences in math performance across ethnic groups $F(3,964448)=37625.7, p<.0001$. Follow-up pairwise comparisons using Tukey's HSD revealed that Vietnamese students $(M=64.1)$ had significantly higher math score with the mean levels higher than the White students (mean differences, $m d=6.39$ ), the Lao/Cambodian students ( $m d=15.13)$, and the African American students ( $m d=23.48)$. Overall, effect sizes in math were in the same direction but higher in magnitude compared reading scores. When compared to African American scores, White $(d=0.81)$ and Vietnamese $(d=1.12)$ were large. The difference between Vietnamese and Lao/Cambodian math scores was medium $(d=0.71)$. All other between group differences were small in size and ranged from $d=0.30$ to $d=0.40$. Table 2 summarizes the means and standard deviations in math by ethnic group, and Table 4 summarizes effect sizes.

Table 2

Mean Levels of Reading and Math for Students in Four Ethnic Groups

\begin{tabular}{|c|c|c|c|c|c|c|c|c|}
\hline & \multicolumn{2}{|c|}{$\begin{array}{c}\text { White } \\
(n=752729)\end{array}$} & \multicolumn{2}{|c|}{$\begin{array}{l}\text { Vietnamese } \\
(n=28737)\end{array}$} & \multicolumn{2}{|c|}{$\begin{array}{c}\text { Lao/Cambodian } \\
(n=13772)\end{array}$} & \multicolumn{2}{|c|}{$\begin{array}{c}\text { African American } \\
(n=169214)\end{array}$} \\
\hline & $M$ & $S D$ & $M$ & $S D$ & $M$ & $S D$ & $M$ & $S D$ \\
\hline Reading & 58.2 & 20.3 & 56.8 & 19.1 & 45.2 & 18.7 & 42.0 & 20.4 \\
\hline Math & 57.7 & 19.7 & 64.1 & 19.0 & 49.0 & 19.4 & 40.6 & 19.4 \\
\hline
\end{tabular}


Table 3

Reading Achievement Effect Size in Standard Deviation Units

\begin{tabular}{lcccc} 
& White & Vietnamese & Lao/Cambodian & African American \\
\hline White & -- & 0.07 & 0.62 & 0.77 \\
Vietnamese & & -- & 0.55 & 0.70 \\
Lao/ Cambodian & & & -- & 0.15 \\
African American & & & & -- \\
\hline
\end{tabular}

Table 4

Math Achievement Effect Size in Standard Deviation Units

\begin{tabular}{lcccc} 
& White & Vietnamese & Lao/Cambodian & African American \\
\hline White & -- & 0.30 & 0.40 & 0.81 \\
Vietnamese & & -- & 0.71 & 1.12 \\
Lao/ Cambodian & & & -- & 0.40 \\
African American & & & & -- \\
\hline
\end{tabular}

\section{Parent Education Differences}

To assess reading performance differences by parents' education, students' mean reading normalized scores were examined between groups. A one-way ANOVA indicated significant differences in reading performance levels between parental education level groups $F(3,964448)$ $=35956.1, p<.0001$. Follow-up pairwise comparisons using Tukey's HSD revealed that parents with college graduate or graduate school education level $(M=62.0)$ had significantly higher reading score with the mean levels higher than the parents with some college education level (mean differences, $m d=8.98, d=0.42)$, the parents with high school graduate level $(m d=14.87)$, and the parents with not a high school graduate $(m d=20.91, d=0.28)$.

\section{Table 5}

Mean Levels of Reading and Math for Students in Four Parental Education Groups

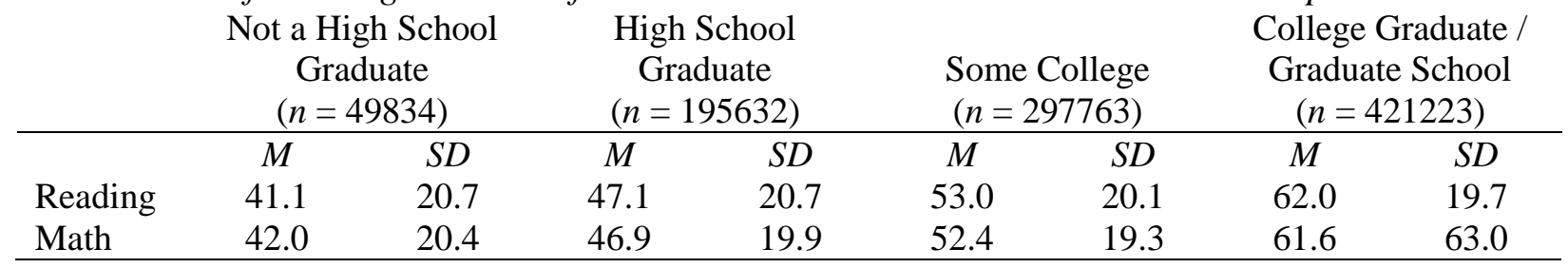

To assess parents' education level differences in math performance, students' math normalized scores were examined for mean level differences across groups. A one-way ANOVA indicated significant differences in math performance levels across parental education level groups $F(3,964448)=35803.1, p<.0001$. Follow-up pairwise comparisons using Tukey's HSD revealed that parents with college graduate or graduate school education level $(M=61.6)$ had significantly higher math scores with the mean levels higher than the parents with some college education level (mean differences, $m d=9.19, d=0.44)$, the parents who are high school graduates $(m d=14.67)$, 
and the parents who did not graduate from high school $(m d=19.58, d=0.28)$. Table 5 summarizes the means and standard deviations in reading by parental education level groups, and Tables 6 and 7 summarize effect size.

\section{Table 6}

\begin{tabular}{lcccc}
$\begin{array}{l}\text { Reading Achievement Effect Size by Level of Education in Standard Deviation } \\
\text { Not a High School } \\
\text { Graduate }\end{array}$ & $\begin{array}{c}\text { High School } \\
\text { Graduate }\end{array}$ & $\begin{array}{c}\text { Some College } \\
\text { College Graduate / } \\
\text { Graduate School }\end{array}$ \\
\hline $\begin{array}{l}\text { Not a High School } \\
\text { Graduate }\end{array}$ & -- & 0.28 & 0.56 & 1.00 \\
$\begin{array}{l}\text { High School } \\
\text { Graduate }\end{array}$ & -- & 0.28 & 0.71 \\
$\begin{array}{l}\text { Some College } \\
\text { College Graduate / } \\
\text { Graduate School }\end{array}$ & & -- & 0.42 \\
\hline
\end{tabular}

Table 7

Math Achievement Effect Size by Level of Education in Standard Deviation Units

\begin{tabular}{lcccc} 
& $\begin{array}{c}\text { Not a High School } \\
\text { Graduate }\end{array}$ & $\begin{array}{c}\text { High School } \\
\text { Graduate }\end{array}$ & $\begin{array}{c}\text { Some College } \\
\text { Graduate School }\end{array}$ \\
\hline $\begin{array}{l}\text { Not a High School } \\
\text { Graduate }\end{array}$ & -- & 0.28 & 0.50 & 0.98 \\
$\begin{array}{l}\text { High School } \\
\text { Graduate }\end{array}$ & -- & 0.26 & 0.69 \\
$\begin{array}{l}\text { Some College } \\
\text { College Graduate / }\end{array}$ & & -- & 0.44 \\
Graduate School & & & -- \\
\hline
\end{tabular}

\section{Socioeconomic Status Differences}

To assess economic social differences in reading performance, students' reading normalized scores were examined for mean level differences across groups. A one-way ANOVA indicated significant differences in reading performance levels across school lunch program $F(1,964450)=99441.5, p$ $<.0001$. Follow-up pairwise comparisons using Tukey's HSD revealed that students who were not in school lunch program $(M=59.1)$ had significantly higher reading score with the mean levels higher than the students who were in the school lunch program (mean differences, $m d=14.49, d$ $=0.69$ ). Table 8 summarizes the means and standard deviations in reading by school lunch program groups.

To assess economic social differences in math performance, students' math normalized scores were examined for mean level differences across groups. A one-way ANOVA indicated significant differences in math performance levels across school lunch program $F(1,964450)=$ $94620.5, p<.0001$. Follow-up pairwise comparisons using Tukey's HSD revealed that students who were not in school lunch program $(M=58.6)$ had significantly higher reading score with the mean levels higher than the students who were in school lunch program (mean differences, $m d=$ $13.84, d=0.66)$ ). Table 8 summarizes the means, standard deviations, and effect sizes in math and reading NCE scores by school lunch program eligibility. 
Table 8

Mean Levels of Reading and Math for Students Eligible for School Lunch Program

\begin{tabular}{|c|c|c|c|c|c|}
\hline & \multicolumn{2}{|c|}{ Eligible $(n=698170)$} & \multicolumn{2}{|c|}{ Not Eligible $(n=266282)$} & \multirow[b]{2}{*}{ Effect Size } \\
\hline & $M$ & $S D$ & $M$ & $S D$ & \\
\hline Reading & 59.1 & 19.9 & 44.6 & 20.8 & 0.69 \\
\hline Math & 58.6 & 19.6 & 44.8 & 20.1 & 0.66 \\
\hline
\end{tabular}

\section{Combined Differences: Ethnicity, Parent Education Levels, and Socioeconomic Status}

Three-way analyses of variance were conducted on the influence of three independent variables (ethnicity, parent education level, school lunch program) on reading and math performance for seventh-grade students. Ethnicity included four groups (Vietnamese, Lao/Cambodian, African American, @ hite), parent education level consisted of four levels (not a high school graduate, high school graduate, some college, college graduate/graduate school), and school lunch program condition contained two groups (no lunch program, yes lunch program.

For reading performance, all effects were statistically significant at the 0.05 significance level and can be found in Table 9. The main effect for ethnicity yielded an F ratio of $F(3,964420)$ $=8266.14, p<.0001, \eta 2=0.02$, indicating a significant difference among White students $(\mathrm{M}=$ 58.2, $\mathrm{SD}=20.3)$, Vietnamese students $(\mathrm{M}=56.8, \mathrm{SD}=19.1)$, Lao/Cambodian students $(\mathrm{M}=45.2$, $\mathrm{SD}=18.7)$, and African American students $(\mathrm{M}=42.0, \mathrm{SD}=20.4)$. The main effect for students in the lunch program or not yielded an $\mathrm{F}$ ratio of $F(1,964420)=2613.2, p<.0001, \eta 2=0.002$, indicating a significant difference between students who were not in the lunch program $(\mathrm{M}=59.1$, $\mathrm{SD}=19.9)$, and students who participated in the lunch program $(\mathrm{M}=44.6, \mathrm{SD}=20.8)$. The main effect for parent education level yielded an $\mathrm{F}$ ratio of $F(3,964420)=1573.1, p<.0001, \eta 2=$ 0.004 , indicating a significant difference among college graduate/graduate school level $(\mathrm{M}=62.0$, $\mathrm{SD}=19.7)$, some college $(\mathrm{M}=53.0, \mathrm{SD}=20.1)$, high school graduate $(\mathrm{M}=47.1, \mathrm{SD}=20.7)$, and not a high school graduate $(\mathrm{M}=41.1, \mathrm{SD}=20.7)$. The predicted interaction between ethnicity and school lunch program condition was also significant, $F(3,964420)=183.12, p<.0001, \eta 2=$ 0.0005. The predicted interaction between ethnicity and parent education level was also significant, $F(9,964420)=66.49, p<.0001, \eta 2=0.0005$. The predicted interaction between school lunch program and parent education level was also significant, $F(3,964420)=126.1, p<$ $.0001, \eta 2=0.0003$. There was a significant three-way interaction among ethnicity, school lunch program and parent education level in reading performance, $F(9,964420)=12.6, p<.0001, \eta 2=$ 0.0001 .

For math performance, all effects were statistically significant at the 0.05 significance level and are shown in Table 10. The main effect for ethnicity yielded an $\mathrm{F}$ ratio of $F(3,964420)=$ $13999.8, p<.0001, \eta 2=0.035$, indicating a significant difference among Vietnamese students $(\mathrm{M}$ $=64.1, \mathrm{SD}=19.0)$, White students $(\mathrm{M}=57.7, \mathrm{SD}=19.7)$, Lao/Cambodian students $(\mathrm{M}=49.0$, $\mathrm{SD}=19.4)$, and African American students $(\mathrm{M}=40.6, \mathrm{SD}=19.4)$. The main effect for students in the lunch program or not yielded an $\mathrm{F}$ ratio of $F(1,964420)=2263.43, p<.0001, \eta 2=0.002$, indicating a significant difference between students were not in lunch program $(\mathrm{M}=58.6, \mathrm{SD}=$ 19.6), and students were in lunch program $(\mathrm{M}=44.8, \mathrm{SD}=20.1)$. The main effect for parent education level yielded an $\mathrm{F}$ ratio of $F(3,964420)=1659.8, p<.0001, \eta 2=0.004$, indicating a significant difference among college graduate/graduate school level $(\mathrm{M}=61.6, \mathrm{SD}=19.6)$, some college $(M=52.4, \mathrm{SD}=19.3)$, high school graduate $(\mathrm{M}=46.9, \mathrm{SD}=19.9)$, and not a high school 
graduate $(M=42.0, S D=20.4)$. The predicted interaction between ethnicity and school lunch program condition was also significant, $F(3,964420)=185.5, p<.0001, \eta 2=0.0005$. The predicted interaction between ethnicity and parent education level was also significant, $F(9$, $964420)=66.49, p<.0001, \eta 2=0.0005$. The predicted interaction between school lunch program and parent education level was also significant, $F(3,964420)=138.4, p<.0001, \eta 2=0.0003$. There was a significant three-way interaction among ethnicity, school lunch program and parent education level in math performance, $F(9,964420)=8.55, p<.0001, \eta 2=0.0001$.

\section{Table 9}

Three-way ANOVA Within-Subjects Effects among Ethnicity, School Lunch Program, and Parent Education Level in Reading Performance

\begin{tabular}{lcrrr}
\hline Source & $d f$ & Type III SS & Mean Square & \multicolumn{1}{c}{$F$ Value } \\
\hline Ethnicity & 3 & 9073302.7 & 3024434.2 & 8266.1 \\
Lunch Program & 1 & 956120.3 & 956120.3 & 2613.2 \\
Parent Education Level & 3 & 1726669.1 & 575556.4 & 1573.1 \\
Ethnicity*Lunch Program & 3 & 201005.4 & 670001.8 & 183.1 \\
Ethnicity*Parent Education Level & 9 & 162259.7 & 18028.9 & 49.3 \\
Lunch*Parent Education Level & 3 & 138414.4 & 46138.1 & 126.1 \\
Ethnicity*Lunch Program*Parent & 9 & 41562.3 & 4618.0 & 12.6 \\
Education Level & & & & \\
\hline
\end{tabular}

Note: $(p<0.0001$ for all comparisons $)$

The significant two-way and three-way interactions among ethnicity, school lunch program, and parent's education level suggest that differences on the school performance among ethnic groups vary as a function of the variables of school lunch program and parent education level. The results demonstrate that school lunch status and parent education levels measure similar social aspects. This leads to interaction among the three areas of ethnic group membership, lunch program, and parent education level.

\section{Table 10}

Three-way ANOVA Within-Subjects Effects among Ethnicity, School Lunch Program, and Parent Education Level in Math Performance

\begin{tabular}{lrrrr}
\hline Source & $d f$ & Type III SS & Mean Square & $F$ Value \\
\hline Ethnicity & 3 & 43305714.2 & 14435238.1 & 42289.2 \\
Lunch Program & 1 & 19236324.0 & 19236324.0 & 56354.3 \\
Parent Education Level & 3 & 19569066.0 & 6523022.0 & 19109.7 \\
& & & & \\
Ethnicity*Lunch Program & 3 & 552849.4 & 184283.1 & 539.9 \\
Ethnicity*Parent Education Level & 9 & 641397.7 & 71263.1 & 208.8 \\
Lunch*Parent Education Level & 3 & 786928.2 & 262309.4 & 768.5 \\
Ethnicity*Lunch Program*Parent & 9 & 26260.8 & 2917.9 & 8.6 \\
Education Level & & & & \\
\hline
\end{tabular}

Note: $(p<0.0001$ for all comparisons $)$ 
The decision was then made to examine simple main effects for ethnicity at each level of other independent variables. Table 11 summarizes ANOVA results for reading and math performances by ethnicity and parent education levels.

In reading performance, the main effect for ethnicity with parent education level at not a high school graduate yielded an $\mathrm{F}$ ratio of $F(3,49830)=1223.58, p<.0001$ while the main effect for ethnicity with parent education level at high school graduate yielded an $\mathrm{F}$ ratio of $F(3,195628)$ $=1757.75, p<.0001$. At the same time, the main effect for ethnicity with parent education level at some college yielded an $\mathrm{F}$ ratio of $F(3,297759)=6629.91, p<.0001$ while the main effect for ethnicity with parent education level at college graduate or graduate school yielded an F ratio of $F$ $(3,421219)=10836, p<.0001$.

\section{Table 11}

Mean Levels of Reading Performance as a Function of Ethnicity for Students from Four Levels of Parent's Education

\begin{tabular}{cccccc}
\hline & $\begin{array}{c}\text { African } \\
\text { American }\end{array}$ & Vietnamese & $\begin{array}{c}\text { Lao / } \\
\text { Cambodian }\end{array}$ & White & \\
\hline $\begin{array}{c}\text { Not a High } \\
\text { School } \\
\text { Graduate }\end{array}$ & 33.05 & 48.95 & 40.64 & 43.97 & $F(3,49830)=1223.6$ \\
\hline $\begin{array}{c}\text { High School } \\
\text { Graduate }\end{array}$ & 37.62 & 54.05 & 45.58 & 49.95 & $F(3,195628)=4757.8$ \\
\hline $\begin{array}{c}\text { Some } \\
\text { College }\end{array}$ & 43.07 & 58.28 & 49.23 & 55.48 & $F(3,297759)=6629.9$ \\
\hline $\begin{array}{c}\text { College } \\
\text { Graduate / } \\
\text { Graduate } \\
\text { School }\end{array}$ & 47.54 & 62.51 & 51.46 & 63.95 & $F(3,421219)=$ \\
& & & & 10836.0 \\
\hline
\end{tabular}

Note: $(p<0.0001$ for all comparisons $)$

In math performance, the main effect for ethnicity with parent education level at not a high school graduate yielded an F ratio of $F(3,49830)=2472.28, p<.0001$ while the main effect for ethnicity group with parent education level at high school graduate yielded an F ratio of $F$ (3, $195628)=7551.54, p<.0001$. At the same time, the main effect for ethnicity with parent education level at some college yielded an $\mathrm{F}$ ratio of $F(3,297759)=8983.22, p<.0001$ while the main effect for ethnicity with parent education level at college graduate or graduate school yielded an $\mathrm{F}$ ratio of $F(3,421219)=13145.7, p<.0001$.

\section{Table 12}

Mean Levels of Math Performance as a Function of Ethnicity for Students from Four Levels of Parent's Education

\begin{tabular}{cccccc}
\hline & $\begin{array}{c}\text { African } \\
\text { American }\end{array}$ & Vietnamese & $\begin{array}{c}\text { Lao / } \\
\text { Cambodian }\end{array}$ & White & \\
\hline $\begin{array}{c}\text { Not a High } \\
\text { School }\end{array}$ & 32.21 & 56.79 & 44.43 & 43.80 & $F(3,49830)=2472.3$ \\
Graduate & & & & & \\
\hline
\end{tabular}




\begin{tabular}{cccccl}
\hline $\begin{array}{c}\text { High School } \\
\text { Graduate }\end{array}$ & 36.29 & 61.83 & 49.15 & 49.69 & $F(3,195628)=7551.5$ \\
\hline $\begin{array}{c}\text { Some } \\
\text { College }\end{array}$ & 41.71 & 65.07 & 52.95 & 54.88 & $F(3,297759)=8983.2$ \\
\hline $\begin{array}{c}\text { College } \\
\text { Graduate / } \\
\text { Graduate } \\
\text { School }\end{array}$ & 45.96 & 69.58 & 55.41 & 63.55 & $F(3,421219)=$ \\
\hline
\end{tabular}

Note: $(p<0.0001$ for all comparisons)

The following tables summarize ANOVA results for reading and math performances by ethnicity groups and school lunch program.

In reading performance, the main effect for ethnicity with students in the school lunch program yielded an $\mathrm{F}$ ratio of $F(3,266278)=5440.78, p<.0001$ while the main effect for ethnicity with students not in the school lunch program yielded an $\mathrm{F}$ ratio of $F(3,698166)=10576.7, p<$ .0001 .

Table 13

Mean Levels of Reading Performance as a Function of Ethnicity for Students from Two Levels of School Program

\begin{tabular}{cccccl}
\hline & $\begin{array}{c}\text { African } \\
\text { American }\end{array}$ & Vietnamese & $\begin{array}{c}\text { Lao / } \\
\text { Cambodian }\end{array}$ & White & \\
\hline $\begin{array}{c}\text { Yes in } \\
\text { School }\end{array}$ & 38.25 & 52.96 & 42.98 & 48.07 & $F(3,266278)=5440.8$ \\
Program & & & & & \\
\hline $\begin{array}{c}\text { Not in } \\
\text { School }\end{array}$ & 46.97 & 61.04 & 51.53 & 60.53 & $\begin{array}{l}F(3,698166)= \\
10576.7\end{array}$ \\
Program & & & & & \\
\hline
\end{tabular}

Note: $(p<0.0001$ for all comparisons $)$

In math performance, the main effect for ethnicity with students in the school lunch program yielded an $\mathrm{F}$ ratio of $F(3,266278)=10334.5, p<.0001$ while the main effect for ethnicity with students not in the school lunch program yielded an $\mathrm{F}$ ratio of $F(3,698166)=13702.0, p<$ .0001 .

Table 14

Mean Levels of Math Performance as a Function of Ethnicity for Students from Two Levels of School Program

\begin{tabular}{cccccc}
\hline & $\begin{array}{c}\text { African } \\
\text { American }\end{array}$ & Vietnamese & $\begin{array}{c}\text { Lao / } \\
\text { Cambodian }\end{array}$ & White & \\
\hline $\begin{array}{c}\text { Yes in } \\
\text { School }\end{array}$ & 37.15 & 60.91 & 46.85 & 48.08 & $F(3,266278)=10334.5$ \\
Program & & & & & \\
\hline $\begin{array}{c}\text { Not in School } \\
\text { Program }\end{array}$ & 45.37 & 67.72 & 54.95 & 60.00 & $F(3,698166)=13702.0$ \\
\hline $\begin{array}{l}\text { Pote: }(p<0.0001 \text { for all comparisons }) \\
\end{array}$
\end{tabular}

Note: $(p<0.0001$ for all comparisons $)$ 


\section{Discussion}

The "model minority" is a stereotype that serves as an obstacle to Asian American groups such as Cambodian American, Laotian American, and Vietnamese American students who are not receiving equality in education. The findings of this study demonstrate that there are Asian American students who like some African American students have problems with reading and math in school. The performance of Cambodian American, Laotian American, and Vietnamese American students is heavily influenced by their socioeconomic status. Students who are participants in the school lunch program perform significantly lower than students who are not members of the school lunch program. In addition, it is important to note that students whose parents have more educational experiences do better in math and reading on the CAT/6 assessment.

This study looked at almost a million students from the state of California who were in the seventh grade in 2003-2008. The findings of this study show the existence of a large achievement gap between Whites and African Americans, Cambodian Americans, and Laotian Americans in reading and math. Whites compared to African Americans do significantly better in both math and reading with high effect sizes. In addition, whites also perform significantly higher than Cambodian American and Laotian students in math and reading, with sizable effect sizes. Though there was a significant difference found between whites and Vietnamese in reading, the effect size was minimal. There was also a significant difference found between Vietnamese American students and their White peers in math where Vietnamese had a higher mean score. The effect size was fairly strong.

Parent education levels among the groups significantly influenced the achievement of all ethnic/racial groups in both reading and math. The researchers in this study believe that school lunch status and parent education levels are highly correlated and therefore demonstrate strong interactions. In addition, both ethnicity and school lunch status, and ethnicity and parent education levels showed interactions. In the United States, income and ethnicity are aspects of society that are highly correlated and shown to make major differences in the achievement of students (Obradović, Long, Cutulli, Chan, Hinz, Heistad, \& Matsen, 2009). Students who are members of low-income score lower than learners who are members of high-income families. There is more risk that these students do not have as many opportunities as students whose parents have higher levels of education and income.

\section{Conclusion}

The study shows the academic needs for reading and math among students of color from African American, Cambodian American, Laotian American, and Vietnamese American families. Intervention is needed for these students in the area of reading. Students of color scored significantly lower than Whites on the reading assessment. There has been much research that has indicated that AAPIs and other students of color need programs that address vocabulary development, writing, and comprehension skills (Kiang \& Kaplan, 1994; Pang, 1990; Pang, Han, \& Pang, 2011; Suzuki, 2002). Many Southeast Asian American students may be English language learners or from second generation families where their parents do not speak Standard English at home; parents may speak a heritage language (Portes \& Rumbaut, 2001; Rumbaut, 1995). Though many children may not speak the heritage language and understand what is spoken, they may not have the language modeling needed to develop high-level vocabulary in English. The children also 
may have more trouble learning how to write because they have not had the opportunity to read print and digital materials if their families have limited financial resources. Writing is difficult for many students because it is a complex process. Students need a strong command of English and have developed high level language skills. Students must be able to think logically and produce a clear argument. We highly recommend that schools develop writing intervention programs for these students to teach them how to effectively communicate in writing.

This study also demonstrated that contrary to the "model minority" myth, Cambodian American and Laotian American students performed significantly lower in math than their White American peers. This again demonstrates the need for schools to provide intervention programs in math for Southeast Asian students along with their African American counterparts. This is probably one of the most serious findings because the stereotype of the nerdy, math and science AAPI student is pervasive within this country. Many teachers do not believe that Asian American students are in need of assistance in mathematics because of this powerful myth.

In summary, not all Southeast Asian American students perform on the same level. There are differences. In this study, Vietnamese American students attained significantly higher levels of achievement in both reading and math than their Cambodian American and Laotian American peers. Looking forward, research that examines differences in gender, generation in the United States, and when student families arrived in the United States may be fruitful areas of investigation. These characteristics may be valuable in explaining the differences between the academic achievement of Vietnamese Americans, Cambodian Americans, and Laotian Americans. There is a great diversity among Southeast Asians and more study is needed.

Finding larger numbers of Southeast Asian Americans could bring to light important elements about the diversity within the community. Though this study examined the performance of three Southeast Asian American communities, the population also includes individuals with ancestry from the Philippines, Thailand, Malaysia, Singapore, and Indonesia. If the achievement of additional Cambodian American and Laotian American students could be located, similar disaggregatee analyses could be performed. Though this study did not have enough students to create two separate groups, Cambodian American and Laotian American students come from distinctly different countries and cultures.

School personnel should also consider providing a parent liaison to assist Cambodian, Laotian, and Vietnamese parents. Even if parents do not speak English well, they can still volunteer in the school. For example, parents may put up bulletin boards, collect library books, and copy materials for teachers. Their efforts help teachers and parents as active members of the school community will learn about what goes on in schools. Parents who would like to participate in schools can contribute to their children's education. Also some parents may want to attend evening Open Houses or PTA meetings. However, if they do not have transportation to the school, some principals have provided buses to pick up and take home parents who live in the neighborhood. This is another way to encourage parent involvement in school affairs.

Cambodian American, Laotian American, African American, and Vietnamese American students need academic interventions in both reading and math. Equal educational opportunity is not being provided to many of these students. The achievement gap between these groups and whites still exists and the "model minority" myth is a major reason for the lack of educational opportunities and interventions needed. 


\section{References}

American Psychological Association. (2010). Publication manual of the American psychological association (6th ed.). Washington, DC: Author.

Cabezas, A. Y., \& Kawaguchi, G. (1988). Empirical evidence for continuing Asian American income inequality: The human capital model and labor market segmentation. In G. Okihiro, S. Hune, A. A. Hansen, \& J. M. Liu (Eds.), Reflections on shattered windows: Promises and prospects for Asian American studies (pp. 144-164). Pullman, WA: Washington State University Press.

Characteristics of College Presidents, 1995. (2000, September 1). The Chronicle of Higher Education. Retreived from http://www.chronicle.com/

Chhuon, V., Hudley, C., Brenner, M. E., \& Macias, R. (2010). The multiple worlds of successful Cambodian American students. Urban Education, 45(1), 30-57. doi:10.1177/0042085909352583

Choi, Y., He, M., \& Harachi, T. W. (2009). Intergenerational cultural dissonance, parent-child conflict and bonding, and youth problem behaviors among Vietnamese and Cambodian immigrant families. Journal of Youth Adolescence, 37(1), 85-96. doi:10.1007/s 10964-0079217-z

Chronicle of Higer Education. (2000). Number of full-time faculty members by sex, rank, and racial and ethnic group. The Chronicle of Higher Education, 47, p. 38.

Cohen, J. (1988) Statistical power analysis for the behavioral sciences (2nd ed.) Hillsdale, NJ: Lawrence Erlbaum.

Ellis, P. D. (2010). The essential guide to effect sizes: Statistical power, meta-analysis, and the interpretation of research results. New York: Cambridge University Press.

Eng, S. (2012). Cambodian early adolescents' academic achievement: The role of social capital. Journal of Early Adolescence, 33(3), 378-403. doi:10.1177/0272431612441069

Federal Glass Ceiling Commission. (1995). Good for business: Making full use of the nation's human capital. Washington, DC: U.S. Government Printing Office.

Gitlin, T. (1982). Television's screens: Hegemony in transition. In M. W. Apple (Ed.), Cultural and economic reproduction in education: Essays on class, ideology, and the state. London, UK: Routledge \& Kegan Paul Books.

Hartlep, N. D. (2013). The model minority? Stereotypes of Asian Americans may hurt more than help. Diverse Issues in Higher Education, 30(2), 564-566.

Hartlep, N. D. (2014). Asian (American) model minorities. Studies on Asia, 4(1), 1-6.

Hartlep, N. D., \& Portfilio, B. J. (2015). Killing the model minority myth: Asian American counterstories and complicity. Charlotte, NC: Information Age Publishing.

Her, C. S. (2014). Ready or not: The academic college readiness of Southeast Asia Americans. Multicultural Perspectives, 16(1), 35-42. doi:10.1080/15210960.2014.872938

Hill, C., H. Bloom, A. Black, \& M. Lipsey. (2007). Empirical benchmarks for interpreting effect sizes in research. New York: MDRC.

Hune, S., \& Chan, K. S. (1997). Special Focus: Asian Pacific American demographic and educational trends. In D. J. Carter \& R. Wilson (Eds.), Fifteenth annual status report on minorities in higher education, 1996-1997 (pp. 43-68). Washington, DC: American Council on Education.

Hyun, J. (2005). Breaking the bamboo ceiling: Career strategies for Asians. New York: Harper Collins. 
Jiobu, R. M. (1988). Ethnicity and assimilation: Blacks, Chinese, Filipinos, Japanese, Koreans, Mexicans, Vietnamese, and White. Albany, NY: State University of New York Press.

Kiang, P. N., \& Kaplan, J. (1994). Where do we stand?: Views on racial conflict by Vietnamese American high school students in a black-and-white context. Urban Review 26(2), 95-119. doi:10.1007/BF02354461

King, P. H., \& Holley, D. (1985). 50,000: Indochinese find haven, pain in the U.S. Los Angeles Times. Retrieved from http://articles.latimes.com/1985-05-01/news/mn-11505_1_ refugees.

Kitano, H. H., \& Daniels, R. (2001). Asian Americans: Emerging minorities. Englewood Cliffs, NJ: Prentice Hall.

Kline R. B. (2004). Beyond significance testing: Reforming data analysis methods in behavioral research. Washington, DC: American Psychological Association.

Kumashiro, K. K. (2008). The seduction of common sense: How the right has framed the debate on America's schools. Teaching for social justice. New York: Teachers College Press.

Lam, K. D. (2015). Youth gangs, racism, and schooling: Vietnamese American youth in a postcolonial context. New York: Palgrave Macmillan.

Lee, K. Y., \& Joo, S.-H. (2005). The portrayal of Asian Americans in mainstream magazine ads: An update. Journalism \& Mass Communication Quarterly, 82(3), 654-671. doi:10.1177/107769900508200311.

Lee, S. J. (1994). Behind the model-minority stereotype: Voices of high-and low-achieving Asian American students. Anthropology \& Education Quarterly, 25(4), 413-429. doi:10.1525/aeq.1994.25.4.04x0530j

Lee, S. J. (2005). Up against whiteness: Race, school, and immigrant youth. New York: Teachers College Press.

Lew, J. (2004). The "other" story of model minorities: Korean American high school dropouts in an urban context. Anthropology and Education Quarterly, 35(3), 303-323. doi:10.1525/aeq.2004.35.3.303

Lew, J. (2006). Burden of acting neither white nor black: Asian American identities and achievement in urban schools. The Urban Review, 38(5), 335-352.

Li, G. (2005). Other people's success: Impact of the "model minority" myth on underachieving Asian students in North America. KEDI Journal of Educational Policy, 2(1), 69-86.

Lipsey, M., Puzio, K., Yun, C., Hebert, M., Steinka-Fry, K., Cole, M., Roberts, M., Anthony, S., \& Busick, M.D. (2012). Translating the statistical representation of the effects of education interventions into more readily interpretable forms. Washington, DC: Government Printing Office.

Mclean, J.E., O'Neal, M.R., \& Barnette, J.J. (2000, November). Are all effect sizes created equal? Paper presented at the annual meeting of the Mid-south Educational Research Association, Bowling Green, KY.

National Commission on Asian American and Pacific Islander Research in Education. (2008). Asian American and Pacific Islanders facts, not fiction: Setting the record straight. New York: Asian Pacific American Institute at New York University and Steinhardt Institute for Higher Education Policy at New York University.

Nguyen, A. T. (2014). Never good enough: The educational journey of a Vietnamese American woman. Multicultural Perspectives, 16(3), 166-169. doi:10.1080/15210960.2014.926748

Obradović, J., Long, J. D., Cutulli, J. J., Chan, C., Hinz, E., Heistad, D., \& Matsen, A. S. (2009). Academic achievement of homeless and highly mobile students in an urban school district: 
Longitudinal evidence on risk, growth, and resilience. Development in Psychopathology, 21(2), 493-518. doi:10.1017/S0954579409000273

Odo, F. (2002). The Columbia history of the Asian American experience. New York: Columbia University Press.

Omi, M., \& Winant, H. (2015). Racial formation in the United States (3rd ed.). New York: Routledge.

Osajima, K. (2008). Asian Americans as the model minority: An analysis of the popular press image in the 1960s and 1980s. In K. A. Ono (Ed.), A companion to Asian American studies (pp. 215-225). Malden, MA: Wiley-Blackwell.

Pang, V. O. (1990). Asian American children: A diverse population. Educational Forum, 55(1), 49-66. doi:10.1080/00131729009339288

Pang, V. O. (1991). The relationship between test anxiety and math achievement in Asian American and European American middle school students. Journal of Research and Development in Education, 24(4), 1-10.

Pang, V. O. \& Cheng, L. L. (1998). Struggling to be heard: The unmet needs of Asian Pacific American children. Albany, NY: State University of New York Press.

Pang, V. O., Han, P., \& Pang, J. M. (2011). Asian American and Pacific Islander students: Equity and the achievement gap. Educational Researcher, 40(8), 378-389. doi:10.3102/0013189X11424222

Pang, V. O., Kiang, P. N., \& Pak, Y. K. (2004). Asian Pacific American students: Challenging a biased educational system. In J. A. Banks \& C. A. M. Banks (Eds.), Handbook of research on multicultural education (2nd ed.) (pp. 542-563). New York: Macmillan.

Park, G. C. (2011). Becoming a "model minority": Acquisition, construction and enactment of American identity for Korean immigrant students. The Urban Review, 43(5), 620-635. doi:10.1007/s11256-010-0164-8

Park, J. H., Gabbadon, N. G., \& Chernin, A. R. (2006). Naturalizing racial differences through comedy: Asian, Black, and White views on racial stereotypes in Rush Hour 2. Journal of Communication, 56(1), 157-177. doi:10.1111/j.1460-2466.2006.00008.x

Petersen, W. (1971). Japanese Americans: Oppression and success. New York: Random House.

Portes, A., \& Rumbaut, R. G. (2001). Legacies: The story of the immigrant second generation. London, UK: University of California Press.

Reyes, A. (2007). Language, identity, and stereotype among Southeast Asian American youth: The other Asian. Mahwah, NJ: Lawrence Erlbaum Associates.

Rumbaut, R. G. (1995). The new Californians: Comparative research findings on the educational progress of immigrant children. In R. Rumbaut \& W. Cornelius (Eds.), California's immigrant children: Theory, research and implications for educational policy (pp. 17-69). San Diego, CA: Center for U.S.-Mexican Studies, University of California.

Shah, B. (2007). Being young, female and Laotian: Ethnicity as social capital at the intersection of gender, generation, 'race' and age. Ethnic and Racial Studies, 30 (1), 28-50. doi:10.1080/01419870601006520

Stokes, B. (1987). "New Rivals in Asia." National Journal, 19, p. 1116.

Sue, S., \& Okazaki, S. (1990). Asian American educational achievements: A phenomenon in search of an explanation. American Psychologist, 45(8), 913-920. doi:10.1037/0003066X.45.8.913 
Suzuki, B. H. (2002). Revisiting the model minority stereotype: Implications for student affairs practice and higher education. New Directions for Student Services, 2002(97), 21-32. doi: $10.1002 /$ ss. 36

Tallmadge, G.K., \& Wood, C.T. (1976). ESEA Title 1 Evaluation and reporting system: User's guide. Mountain View, CA: RMC Research Corp.

U.S. Census Bureau. (2011). 2007-2009 American community survey, 3-year estimates. Retrieved from https://www.census.gov/newsroom/releases/archives/american_community_survey _acs/2011-01-11_acs.html

U.S. Census Bureau. (2015). Income and poverty in the United States: 2014, Issued by Carmen DeNavas-Walt. Retrieved from https://www.census.gov/content/dam/Census/ library/ publications/2015/demo/p60-252.pdf

U.S. Department of Agriculture. (2013). National school lunch program fact sheet. Retrieved from http://www.fns.usda.gov/sites/default/files/NSLPFactSheet.pdf.

Walker-Moffat, W. (1995). The other side of the Asian American success story. San Francisco: Jossey-Bass.

Wallace, J. (1982, August 23). The festering irritation with Japan. U.S. News \& World Report, p. 39.

Wing, J. Y. (2007). Beyond Black and White: The model minority myth and the invisibility of Asian American students. The Urban Review, 39(4), 455-487. doi:10.1007/s11256-0070058-6

Wong, P., \& Nagasawa, R. (1991). Asian American scientists and engineers: Is there a glass ceiling for career advancement? Chinese American Forum, 6, 307-338.

Woo, D. (2000). Glass ceilings and Asian Americans: The new face of workplace barriers. Walnut Creek, CA: Altamira Press.

Yuen, N. W., Chin, C., Deo, M., Lee, J., \& Milman, N. (2005). Asian Pacific Americans in prime time: Lights, camera and little action. Washington, DC: The National Asian Pacific American Legal Consortium.

Zakeri, B. (2015). A double-edged sword: Side effects of the model minority stereotype on Asian immigrants in the U.S. In N. D. Hartlep (Ed.), Modern societal impacts of the model minority stereotype (pp. 231-258). Hershey, PA: IGI.

Zhang, Q. (2010). Asian Americans beyond the model minority stereotype: The nerdy and the left out. Journal of International and Intercultural Communication, 3(1), 20-37. doi:10.1080/17513050903428109 


\section{About the Authors}
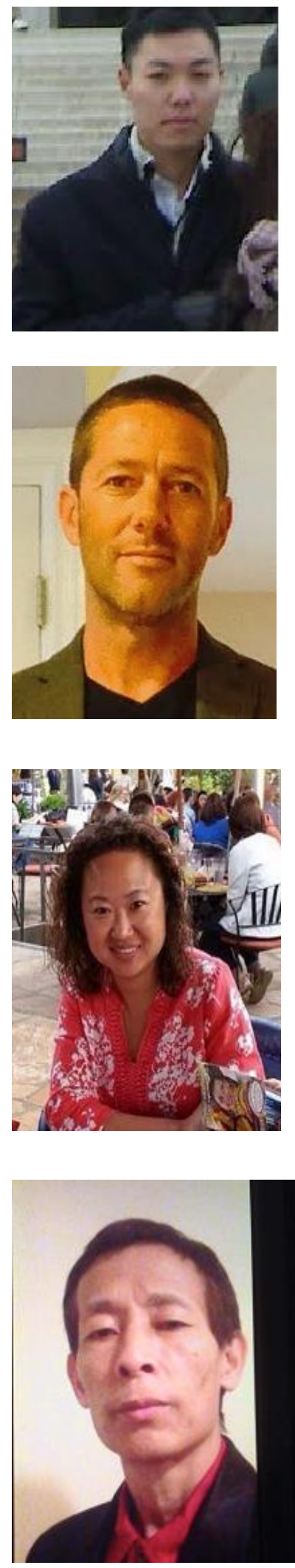

David M. Lee is a doctoral student in the San Diego State University/Claremont Graduate University Joint Doctoral Program in Education. His research centers on the ethic of care, Asian Americans within education, the "model minority" stereotype, as well as differential achievement among AAPI students. Lee's scholarship grows out of having studied and taught in various countries around the world.

Luke Duesbery is an associate professor in the School of Teacher Education and Director for the Center for Teaching Critical Thinking and Creativity at San Diego State University. Dr. Duesbery's primary teaching area is in research methods, special education, and assessment. His research interests are varied and span inclusive pedagogy, assessment, educational technology, and teaching critical thinking and math. He earned his Ph.D. from the University of Oregon.

Peggy P. Han is a Senior Data Analyst in the TRICARE Health Plan Division at Defense Health Agency (DHA). Her research interests are in military injury and huge longitudinal data analyses. She has authored several papers in various journals including Educational Researcher, Am Journal of Public Health, Journal of Trauma, Brain Injury, and Journal of Experimental Medicine. She provides scientific consultations for various colleagues and master degree students for their thesis researches.

Tashi Thupten is currently pursuing Ph.D. in Education from Claremont Graduate University and San Diego State University Joint Program. He has had experience working as interpreter, Tibetan language teacher, translator, and guest speaker over the years. As translator, his works appeared in the Journal of the Institute of Buddhist Dialectics, India. His research focuses on teaching, learning and culture. He speaks five languages. 


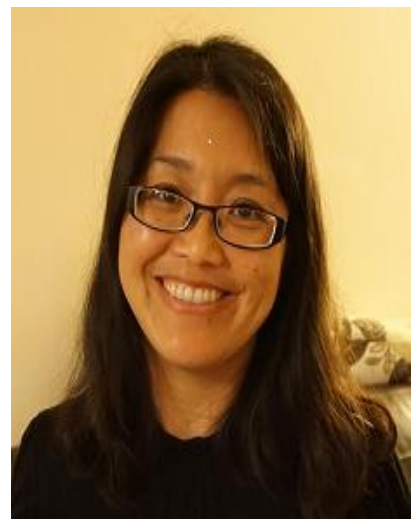

Chia S. Her is a doctoral student in the San Diego State University and Claremont Graduate University Joint Ph.D. program in Education. Her research interests are in the educational trajectories and experiences of racial and ethnic low-income, first-generation college students, specifically in the areas of access, persistence, and degree attainment. She has published in Multicultural Perspectives and contributed to a chapter included in the reference text, Killing the Model Minority Stereotype.

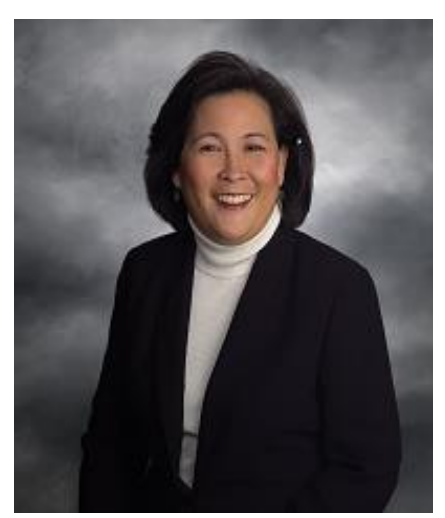

Valerie Ooka Pang is a professor in the School of Teacher Education at San Diego State University. She has published several books on equity and diversity in the classroom. She also was senior editor of Struggling To Be Heard: The Unmet Needs of Asian American Children. Her research has appeared in journals such as Educational Researcher, Harvard Educational Review, and AAPI Nexus. Pang was a senior Fellow for the Annenberg Institute for School Reform at Brown University and honored by organizations such as the American Educational Research Association's Standing Committee on the Role and Status of Minorities in Education, National Association for Multicultural Education, and the University of Washington's College of Education. 


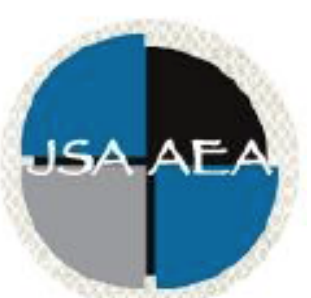

\section{Journal of Southeast Asian American \\ Education and Advancement}

Vol.12 Iss.2 Special Issue (2017)

www.JSAAEA.org

Special Issue Editor

Dr. Nicholas D. Hartlep

Metropolitan State University

\section{Editor}

Dr. Wayne E. Wright

Purdue University

Associate Editors

Dr. Chhany Sak-Humphry

University of Hawaii at Manoa

Dr. Phitsamay Sychitkokhong Uy

University of Massachusetts, Lowell

\section{Book Review Editor \\ Dr. Vichet Chhuon}

University of Minnesota

Creative Works Editor

Bryan Thao Worra

Lao Assistance Center

\section{Journal Manager}

Sung Ae Kim

Purdue University

\section{Editorial Review Board}

\author{
Dr. Steve Arounsack \\ California State University, Stanislaus \\ Dr. Sovicheth Boun \\ The State University of New York, \\ Fredonia
}

Dr. Carl L. Bankston III

Tulane University

Dr. Angela Reyes

Hunter College, The City University of New York 


\author{
Dr. George Chigas \\ University of Massachusetts, Lowell \\ Dr. Hien Duc Do \\ San Jose State University \\ Dr. Sophal Ear \\ Occidental College \\ Dr. Virak Chan \\ University of Texas at San Antonio \\ Dr. Jeremy Hein \\ University of Wisconsin, Eau Claire \\ Dr. Nancy H. Hornberger \\ University of Pennsylvania \\ Dr. Peter Nien-Chu Kiang \\ University of Massachusetts, Boston \\ Dr. Ha Lam \\ Eastern Mennonite University \\ Dr. Jonathan H. X. Lee \\ San Francisco State University \\ Dr. Monirith Ly \\ Royal University of Phnom Penh \\ Dr. Bic Ngo \\ University of Minnesota \\ Dr. Leakhena Nou \\ California State University, Long Beach \\ Dr. Mark Pfeifer \\ SUNY Institute of Technology \\ Dr. Loan T. Phan \\ University of New Hampshire \\ Dr. Kalyani Rai \\ University of Wisconsin, Milwaukee \\ Dr. Cathy J. Schlund-Vials \\ University of Connecticut, Storrs \\ Dr. Nancy J. Smith-Hefner \\ Boston University \\ Dr. Yer J. Thao \\ Portland State University \\ Dr. Monica M. Trieu \\ Purdue University \\ Dr. Silvy Un \\ Saint Paul Public Schools \\ Dr. Terrence G. Wiley \\ Center for Applied Linguistics
}

Dr. Loan Dao

University of Massachusetts, Boston

Dr. Changming Duan

University of Missouri, Kansas City

Dr. Sothy Eng

Lehigh University

Dr. Zha Blong Xiong

University of Minnesota

Dr. Vincent K. Her

University of Wisconsin, Eau Claire

Dr. Peter Tan Keo

New York University

Dr. Kevin K. Kumashiro

University of San Francisco

Dr. Ravy Lao

California State University, Los Angeles

Dr. Stacey Lee

University of Wisconsin, Madison

Dr. Sue Needham

California State University, Dominguez Hills

Dr. Max Niedzwiecki

Daylight Consulting Group

Dr. Clara Park

California State University, Northridge

Dr. Giang Pham

University of Massachusetts

Dr. Karen Quintiliani

California State University, Long Beach

Dr. Phala Chea

Lowell Public Schools

Dr. Fay Shin

California State University, Long Beach

Dr. Christine Su

Ohio University

Dr. Alisia Tran

Arizona State University

Dr. Khatharya Um

University of California, Berkeley

Dr. Linda Trinh Vo

University of California, Irvine

Dr. Yang Sao Xiong

University of Wisconsin-Madison 


\section{Doctoral Student Editorial Review Board}

\author{
Anna H. Yang \\ University of Georgia \\ Annie BichLoan Duong \\ San Joaquin County Office of Education \\ Hoa Nha Nguyen \\ Boston College \\ Malaphone Phommasa \\ Marshall University \\ Molly Wiebie \\ The University of Texas at Austin
}

\author{
Dung Minh Mao \\ University of Minnesota \\ Thien-Huong Ninh \\ University of Southern California \\ Krissyvan Truong \\ Claremont Graduate University \\ Soua Xiong \\ San Diego State University \& Claremont \\ Graduate University
}

